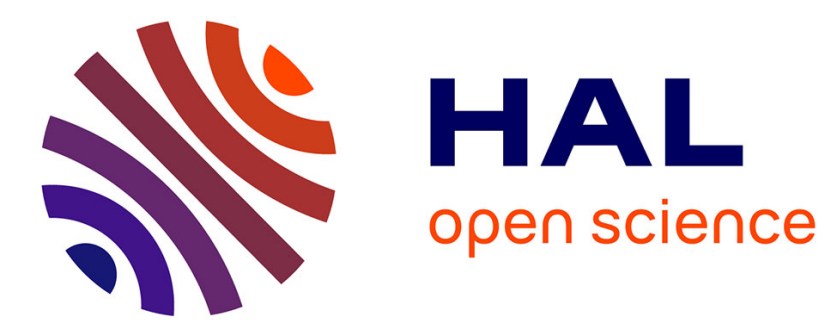

\title{
Reactor scale study of self-heating and self-ignition of torrefied wood in contact with oxygen
}

Brieuc Evangelista, Patricia Arlabosse, Alexandre Govin, Sylvain Salvador, Olivier Bonnefoy, Jean-Louis Dirion

\section{- To cite this version:}

Brieuc Evangelista, Patricia Arlabosse, Alexandre Govin, Sylvain Salvador, Olivier Bonnefoy, et al.. Reactor scale study of self-heating and self-ignition of torrefied wood in contact with oxygen. Fuel, 2018, 214, pp.590-596. 10.1016/j.fuel.2017.11.048 . hal-01650705

\section{HAL Id: hal-01650705 https://hal.science/hal-01650705}

Submitted on 8 Jan 2018

HAL is a multi-disciplinary open access archive for the deposit and dissemination of scientific research documents, whether they are published or not. The documents may come from teaching and research institutions in France or abroad, or from public or private research centers.
L'archive ouverte pluridisciplinaire HAL, est destinée au dépôt et à la diffusion de documents scientifiques de niveau recherche, publiés ou non, émanant des établissements d'enseignement et de recherche français ou étrangers, des laboratoires publics ou privés. 


\section{Reactor scale study of self-heating and self-ignition of torrefied wood in contact with oxygen.}

Brieuc Evangelista ${ }^{a}$, b, ${ }^{*}$, Patricia Arlabosse ${ }^{b}$, Alexandre Govin ${ }^{a}$, Sylvain Salvador ${ }^{b}$, Olivier Bonnefoy ${ }^{a}$, JeanLouis Dirion $^{b}$

a École des Mines de Saint-Étienne, SPIN, CNRS 5307, LGF, 158 cours Fauriel, 42023 Saint-Etienne, France

${ }^{b}$ École des Mines d'Albi-Carmaux, RAPSODEE, CNRS 5302, Université de Toulouse, Allée des sciences 81013 Albi, France

*Corresponding author: brieuc.evangelista@emse.fr

Abstract: This experimental work aims at investigating the potential development of self-heating when torrefied wood chips enter into contact with oxygen. Two kilograms of dried beech chips have been torrefied under nitrogen in a cylindrical reactor at $250^{\circ} \mathrm{C}$ or $285^{\circ} \mathrm{C}$. The temperature was then leveled down between $100^{\circ} \mathrm{C}$ and $160^{\circ} \mathrm{C}$ and nitrogen flow was replaced by oxygen-containing flow. Influences of oxygen volumetric fraction and sweeping gas flow rate were investigated. Temperatures at different bed locations and gaseous product volumetric fractions at the bed output were monitored continuously. In some of the experiments a limited temperature rise was observed while in others a temperature runaway occurred. Thermal considerations indicate a clear enhancement of self-heating propensity with the severity of torrefaction. Gas phase analysis and molecule oxygen balance reveal an adsorption mechanism pathway and a higher rate of oxygen adsorption for the severely torrefied wood. Lowering the oxygen volumetric fraction or increasing the flow rate decrease self-heating behavior and was used to stop selfignition of the bed.

Keywords: self-heating, self-ignition, torrefaction, wood char

\section{Introduction:}

Large scale transition from fossil to renewable energy production requires the use of wood as a solid fuel. Thermochemical processes like combustion, co-combustion or gasification support this development. 
However, compared to coal, natural wood has a low energy density, a high water content, a poor grindability and a poor durability against biodegradation [1]. These weak fuel properties impede the handling and processability of wood and slow down the development of the wood-to-energy sector [2]. Thus, pretreatments are worthwhile considered to overcome these weaknesses. They provide higher grade raw material for thermochemical processes and they strengthen this valorization path. Among them, torrefaction is a mild pyrolysis process suitable for upgrading the fuel properties of wood [3][4]. It is typically carried out at $250-300^{\circ} \mathrm{C}$ in an atmosphere depleted of oxygen. It is seen as a promising thermochemical pretreatment [5] and its large scale development is expected for the decade to come [6]. However, the development of torrefaction raises safety issues. Indeed, combustible materials are liable to oxidation and are therefore prone to self-heating and self-ignition [7]. Moreover, the associated risks are boosted by production and handling scale up [8].

Self-heating leads to a temperature rise and occurs when exothermic reactions, like oxidation, release heat faster than the dissipation rate of the bulk material. Hazard and risk issues are raised since the temperature increase generally promotes the heat generation and might naturally leads to self-ignition, the critical state of self-heating. Transition from self-heating to self-ignition is characterized by a thermal runaway of the exothermic reactions. Franck-Kamenetskii's theory provides a safety design tool by superimposing an exothermic Arrhenius law to a Newton's law of cooling and shows that these phenomena are inherently related to the size of the bulk material considered [9]. Indeed, self-heating occurs when the cooling capacity becomes limiting enough, i.e when the bulk material is large enough.

Self-heating studies are generally based on the Franck-Kamenetskii method [9], the crossing point method [10] or the heat release method [11]. They are based on direct temperature measurements inside a bulk material. They estimate the self-heating kinetic parameters and provide by extrapolation the self-ignition temperature for a given size. An Arrhenius temperature dependency is generally observed for coals [12] 
and for carbonaceous feedstocks [13]. Self-ignition is a well-recognized phenomenon for biomass and for coal [14][15][16]. Self-ignition of torrefied wood has been experienced in laboratory [17][18] and suspected at the industrial scale [17] but literature is rather scarce for this material. To the best of our knowledge, there is no study that investigates the influence of torrefaction severity at the reactor scale.

In the coal industry, the low temperature oxidation has been and remains a question of particular interest. Literature review can be found elsewhere [19]. Researches have put forward an adsorption mechanism pathway [20]. Moreover, results show that oxygen is at least chemisorbed on a carbon atom located on the coal surface [21] and forms a complex which is further decomposed into gaseous products [22] which are mainly carbon oxides $\left(\mathrm{CO}, \mathrm{CO}_{2}\right)$ and water [23][24]. The quantities of adsorbed oxygen [25] and gaseous products generated [26] are very low when there is no ignition. However, there is no consensus about the mechanism of the reaction [19]. Recently, the reactivity of torrefied materials with oxygen has been investigated. Results seem to indicate that torrefaction severity increases the rate of heat generation. This has been shown by direct heat flow measurements [27][28] or by indirect adsorption rate measurement [27].

In the context of production scale up, the question of whether or not torrefaction enhances self-heating propensity is of interest. The aim of this work is to answer this question at the reactor scale.

\section{Materials and methods:}

\subsection{Raw materials and experimental device}

Wood was provided by SoWood Argenteuil, France and consisted of laboratory grade beech chips. Their average length, width and thickness are about 8,4 and $2 \mathrm{~mm}$, respectively.

Figure 1 shows the experimental device used in this study. Experiments were carried out in a stainless steel cylinder of $40 \mathrm{~cm}$ height and $20 \mathrm{~cm}$ diameter. Holes of $1.5 \mathrm{~mm}$ diameter were drilled in the peripheral reactor surface to instrument the bed with K-type thermocouples at 10,15 and $20 \mathrm{~cm}$ 
elevation $( \pm 1 \mathrm{~cm}$ ) along the cylinder axis and above the bottom of the bed. The reactor was inserted in a cylindrical oven heated by lateral heating elements. The upstream gas flow was admitted in the reactor through a bottom perforated plate. Between the reactor and the oven, the airtightness was achieved by compressing a carbon-graphite gasket.

The gas flow rate was measured and monitored by two mass flowmeters (Brooks, SLA5851S). A gas preheater was used to monitor the temperature of the gas flow at the inlet of the reactor. At the output of the reactor, the gas flow was cooled down in a counter-current heat exchanger. The liquid obtained from gas condensation was extracted and treated as a waste. Before being cleaned in an activated carbon filter and released to the atmosphere, part of the non-condensable gases was pumped, cleaned and analyzed. Gas analyzers were used to measure the volumetric fraction of carbon monoxide, from 0 to 3000 ppm, oxygen, from 0 to $25 \%$ (Servopro 4900, Servomex, UK) and carbon dioxide, from 0 to $20 \%$ (Servopro 1440, Servomex, UK).

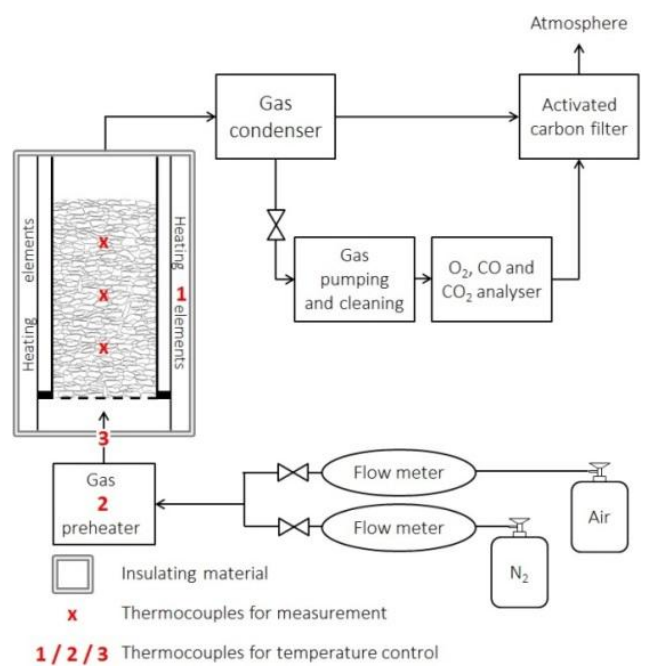

Figure 1: schematic representation of the experimental device use in this study

\subsection{Experimental protocol}

The experimental protocol was divided in two steps. The first one was the preparation of the bed for studying self-heating and involved drying, torrefaction and cooling. The second step was the introduction 
of an oxygen-containing gas through the torrefied bed. Time $t_{i}$ will refer to the moment when oxygen is introduced in the reactor at the temperature $T_{i}$.

Drying was achieved outside of the reactor. About $2.23 \pm 0.005 \mathrm{~kg}$ of natural wood chips were dried during 24 hours in an oven at $105^{\circ} \mathrm{C}$. A dried wood mass of $2.01 \pm 0.01 \mathrm{~kg}$ was then introduced in the reactor. The height of the bed was measured at three different locations. The oven was closed with an insulated hat and nitrogen was then admitted at a flow rate of $30 \mathrm{NL} \cdot \mathrm{min}^{-1}$. The temperature of the lateral oven heating elements (controlled by thermocouple 1 on Figure 1) was set to the desired torrefaction temperature, 250 or $285^{\circ} \mathrm{C}$ for mild or severe torrefaction, respectively. The temperature of the gas preheater heating elements (controlled by thermocouple 2 on Figure 1 ) was set to match the inlet gas flow temperature (measured by thermocouple 3 on Figure 1) with the lateral heating elements temperature. The heating was achieved at a rate of $5^{\circ} \mathrm{C} \cdot \mathrm{min}^{-1}$ for both the oven and the preheater. The duration of the torrefaction palier was kept constant at $1 \mathrm{~h}$ for all of the experiments. At the end of the palier, the set point temperature was leveled down to the desired temperature $T_{i}$.

Fifteen minutes after the set point temperature was reached for both of the heating devices, oxygencontaining gas was admitted in the reactor at a flow rate of 10,20 or $30 \mathrm{NL}$. $\mathrm{min}^{-1}$ and at a volumetric fraction of 7,14 or $21 \%$, on volume basis. To stop an experiment after self-heating observation, the heating devices were switched off, the bed was cooled down to around $40^{\circ} \mathrm{C}$ under air flow and the reactor was opened. Output gases were analyzed from the beginning of the fifteen minutes.

\subsection{Global and local characterizations}

After opening the reactor, the height of the torrefied bed was measured at the same locations as that of the dried bed. The chips were recovered from the reactor by using a pre-weighted vacuum cleaner. As presented in equations (1) and (2), the weight of the bed was used to calculate the overall anhydrous 
weight loss (AWL, [\%]). Dimensions were used to calculate the anhydrous volume loss of torrefaction (AVL, $[\%])$.

$$
\begin{gathered}
A W L=\left(m_{d r y}-m_{t o r r}\right) / m_{d r y} \\
A V L=\left(V_{d r y}-V_{t o r r}\right) / V_{d r y}
\end{gathered}
$$

where $m$ corresponds to a mass $[\mathrm{kg}]$ and $V$ to a volume $\left[\mathrm{m}^{3}\right], d r y$ and torr indices refer to dry and torrefied beds, respectively.

Two reference torrefactions were carried out at 250 and $285^{\circ} \mathrm{C}$. For these experiments, the oxygencontaining gas was not admitted in the reactor until complete cooling and thus no self-heating was generated. During these chips recovery, sampling was performed along the cylinder axis at 20, 15 and 10 $\mathrm{cm}$ elevation. Additional sampling was achieved near the reactor wall, three at $10 \mathrm{~cm}$ and three at $20 \mathrm{~cm}$ elevation. Raw wood and reference torrefied chips samples were ground with a knife mill (Pulverisette 15, Fritsch, Germany) equipped with a $0.5 \mathrm{~mm}$ trapezoidal grid and further dried at $105^{\circ} \mathrm{C}$ overnight. Three elementary analyses were done for each sample using a CHNS elemental analyzer (NC 2100, CE Instruments, England). The sulfur content was below the detection limit, the nitrogen content was always inferior to $0.3 \%$ and the oxygen content was obtained by difference. The atomic ratios $\mathrm{O} / \mathrm{C}$ and $\mathrm{H} / \mathrm{C}$ were calculated from these results. For each sample, relative variation was close to $0.5 \%$.

\subsection{Data processing}

When the oxygen-containing gas was introduced in the reactor, three scenarios were observed: no significant temperature rise, self-heating or self-ignition. Figure 2 depicts such experimental results. Selfheating will be discussed in terms of initial speed of the temperature rise $\left(\mathrm{V}_{\mathrm{SH}},\left[{ }^{\circ} \mathrm{C} \cdot \mathrm{min}^{-1}\right]\right)$ and maximum temperature overshoot $\left(\Delta \mathrm{T}_{S H},\left[{ }^{\circ} \mathrm{C}\right]\right)$ as represented in Figure 2. Self-ignition is discussed as whether or not it happens. 


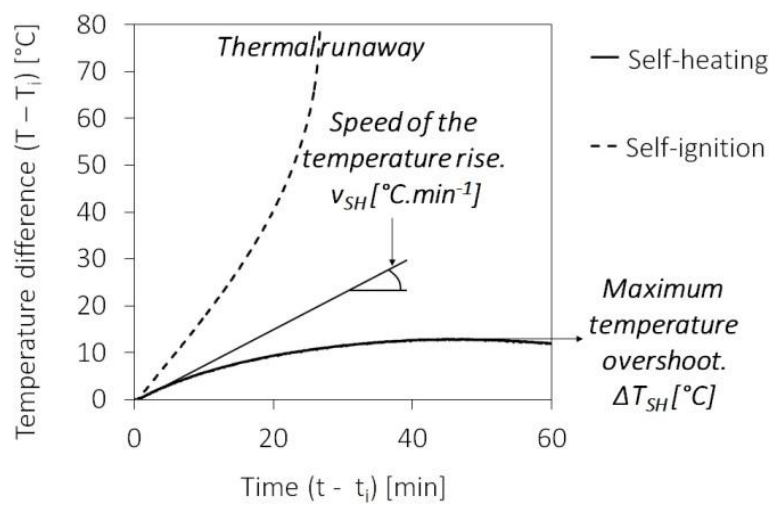

Figure 2 : characteristics of self-heating and self-ignition. Air was introduced at $30 \mathrm{NL} \cdot \mathrm{min}^{-1}$ in the severely torrefied packed bed at 130 and $150^{\circ} \mathrm{C}$ for safe self-heating and self-ignition, respectively.

Output gases are considered as perfect gases with constant molar volume. Carbon oxides and oxygen fractions will refer to the volumetric fraction of these components measured in the gas phase at the bed output. They are used to calculate the carbon oxides production rate $\left(q_{\mathrm{CO}+\mathrm{CO}_{2}},\left[\mathrm{NmL} \cdot \mathrm{min}^{-1} \cdot \mathrm{kg}^{-1}\right]\right)$, the oxygen consumption rate $\left(q_{O_{2}},\left[\mathrm{NmL} \cdot \mathrm{min}^{-1} \cdot \mathrm{kg}^{-1}\right]\right)$ and the molar ratio between carbon monoxide and carbon dioxide $\left(\mathrm{R}_{\mathrm{CO} / \mathrm{CO}_{2}}\right.$, $\left.\left[\mathrm{mol} . \mathrm{mol}^{-1}\right]\right)$. They are defined by equations, (3), (4) and (5) respectively.

$$
q_{\mathrm{CO} \mathrm{CO}_{2}}=\left(Y_{\mathrm{CO}}+Y_{\mathrm{CO}_{2}}\right) \cdot Q / m_{\text {torr }}
$$

where $Y_{\mathrm{CO}}+\mathrm{Y}_{\mathrm{CO}_{2}}$ is the sum of carbon oxides maximum fraction of the gas phase [\%] and $Q$ the flow rate [NL. $\left.\mathrm{min}^{-1}\right]$.

$$
q_{O_{2}}=\left(Y_{O_{2} \text { ref }}-Y_{O_{2}}\right) \cdot Q / m_{\text {torr }}
$$

where $Y_{\mathrm{O}_{2} \text { ref }}$ is the fraction of oxygen in air equal to $20.95 \%$ and $Y_{\mathrm{O}_{2}}$ the minimum oxygen fraction measured at the reactor output [\%].

$$
R_{\mathrm{CO} / \mathrm{CO}_{2}}=Y_{\mathrm{CO}} / Y_{\mathrm{CO}_{2}}
$$

where $Y_{\mathrm{CO}}$ and $Y_{\mathrm{CO}_{2}}$ are the $\mathrm{CO}$ to $\mathrm{CO}_{2}$ fraction, respectively [\%].

\section{Results and discussion:}

The experimental results are discussed in two parts: the first one is related to the bed preparation and is focused on the severity and the homogeneity of the bed torrefaction. The second one is related to selfheating and is focused on self-heating propensity and gaseous products generation. 


\subsection{Fixed bed torrefaction}

Table 1 depicts the global characteristics of the bed after an experiment. No difference is found between reference torrefaction and torrefaction followed by a self-heating if there is no ignition. Oxygen reactivity with torrefied wood appears not to imply a significant amount of mass compared to the mass loss of torrefaction. As expected, the AWL and the AVL increase with the severity of torrefaction. A higher temperature of torrefaction rises the amount of devolatilized and carbonized wood cell wall polymers [3]. The shrinkage is more pronounced at elevated temperature [29]. Interestingly, for both of the torrefied beds, the AWL is nearly 1.6 larger than the AVL. As a direct consequence, the total porosity of the beds remains constant with torrefaction severity.

\begin{tabular}{|c|c|c|c|c|c|c|}
\hline & \multicolumn{2}{|c|}{ Dry bed } & \multicolumn{2}{|c|}{ Mildly torrefied bed } & \multicolumn{2}{|c|}{ Severely torrefied bed } \\
\hline Elevation $[\mathrm{cm}]$ & 26.8 & $(0.9)$ & 25.0 & $(0.6)$ & 23.0 & $(0.8)$ \\
\hline Dry mass [kg] & 2.01 & $(0.01)$ & 1.79 & $(0.03)$ & 1.53 & $(0.02)$ \\
\hline AWL [\%] & & & 10.5 & $(1.0)$ & 23.9 & $(1.0)$ \\
\hline AVL [\%] & & & 6.9 & $(2.4)$ & 14.1 & (3.0) \\
\hline
\end{tabular}

Table 1: average values and (standard deviation) of dimension and mass of dry and torrefied beds. Calculated AWL and AVL are also presented.

Results from elementary analysis are presented in Table 2. A classical decrease of the $\mathrm{O} / \mathrm{C}$ and $\mathrm{H} / \mathrm{C}$ atomic ratios with the increase of torrefaction severity is observed [1]. This results from the thermal degradation of wood in oxygenated gas species such as water, carbon oxides and others organic compounds [30]. An increase of the carbon content and a decrease of the hydrogen content with the sampling elevation can also be noticed. This implies a slightly higher torrefaction severity with the elevation in the bed. This is confirmed by the temperature monitoring. Indeed, even if the upper parts of the bed heat up more slowly, they also cool down more slowly. Globally, they remain a longer time at temperatures where torrefaction reactions occur, i.e. above $200^{\circ} \mathrm{C}$ [3]. Despite these differences, the torrefaction severity along the reactor axis is quite uniform. Moreover, the elementary analysis results in horizontal planes are 
close, within $1.5 \%$ of standard deviation. Therefore the torrefaction severity inside of the bed will be assumed as homogeneous.

\begin{tabular}{|c|c|ccccc|}
\cline { 2 - 6 } \multicolumn{1}{c|}{$\begin{array}{c}\text { Height of } \\
\text { sampling } \\
{[\mathrm{cm}]}\end{array}$} & $\begin{array}{c}\text { Elemental } \\
\text { composition } \\
{[\%]}\end{array}$ & Atomic ratio \\
\cline { 3 - 6 } Raw material & & $\mathrm{C}$ & $\mathrm{H}$ & $\mathrm{O} / \mathrm{C}$ & $\mathrm{H} / \mathrm{C}$ \\
\hline Mildly torrefied bed & 10 & 50.1 & 6.1 & 0.70 & 1.51 \\
\hline & 15 & 50.5 & 6.0 & 0.64 & 1.42 \\
Severely torrefied bed & 15 & 51.2 & 5.9 & 0.63 & 1.38 \\
\hline & 10 & 52.5 & 5.8 & 0.59 & 1.33 \\
& 20 & 53.6 & 5.7 & 0.57 & 1.29 \\
\hline
\end{tabular}

Table 2: elementary analysis of dry and reference torrefied wood.

\subsection{Self-heating}

\subsubsection{Self-heating propensity}

Figure 3 presents typical temperature evolution records inside the bed during a self-heating. At constant air flow rate, it is admitted that the temperature rise reaches a maximum because of a reactant depletion decreasing the heat generation rate [31]. More precisely, as the oxygen consumption is very low [25], its adsorption on wood surface is limited by the number of available reactive sites on the solid. One can notice on Figure 3 that the self-heating speed does not depend on the thermocouple elevation inside the bed. Indeed, initial temperature measurements at 10, 15 and $20 \mathrm{~cm}$ elevation were always closer than $2^{\circ} \mathrm{C}$. Moreover, the oxygen fraction is rapidly well-established in the bed compared to the characteristic duration of self-heating, i.e. 30 minutes. Thus, we assume that, at time $t_{i}$, the bed is uniform in terms of temperature, torrefaction severity and oxygen fraction. Therefore, the heat generation term is homogeneous. However, the maximum temperature overshoot increases with the thermocouple elevation in the bed. By assuming a constant heat transfer coefficient between wood chips and flowing gas and also a constant exchange surface area between the solid and the gas during torrefaction, the 
cooling rate is proportional to the temperature difference between the solid and the gas phase. As the flow is ascending, the amount of heat evacuated by advection decreases from the bottom to the top of the bed and explains partly this result. Nevertheless, because of complex coupled phenomena, process modelling is required to explain this behavior in further details. Reproducibility of self-heating was tested by three replicates for an initial temperatures of 130 and $150^{\circ} \mathrm{C}$ for the severely and the mildly torrefied beds, respectively. For these experiments, the relative standard deviations for the self-heating speed and for the maximum temperature overshoot are about $30 \%$. This is quite satisfactory for a bed of a few kilograms. The main variations might arise from changing chips arrangement, which disturbs the advection through the bed and thus, the local cooling capacity.

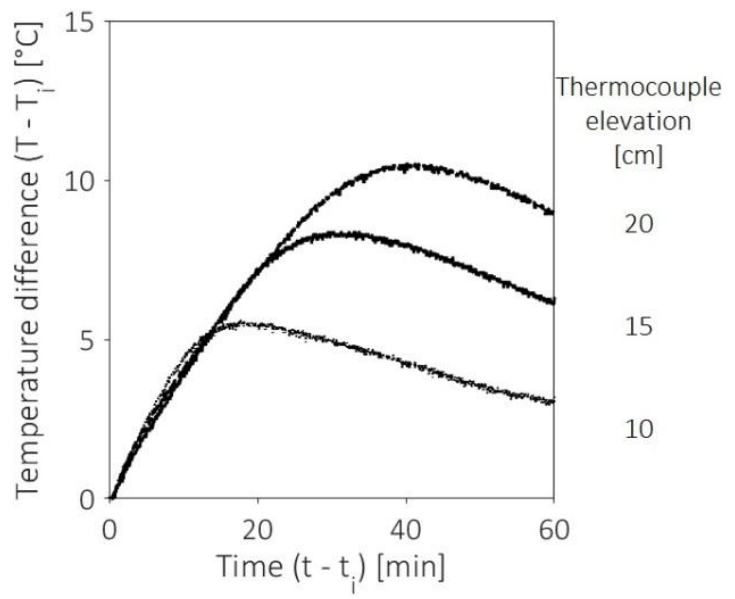

Figure 3: temperature measurements along the reactor axis. Air was introduced in the severely torrefied bed at $30 \mathrm{NL} . \mathrm{min}^{-1}$ and $130^{\circ} \mathrm{C}$.

Figure 4 presents the evolution of the self-heating speed with the initial temperature and the severity of torrefaction. Results are represented for all the thermocouple elevations. A coarse linear tendency is observed between the logarithm of the self-heating speed and the inverse of the initial temperature. Under similar experimental conditions, the self-heating speed is about 4 times higher when the AWL is doubled. It can be clearly concluded that the severely torrefied bed generates heat faster than the mildly torrefied bed. This result is consistent with previous findings related to the low temperature oxidation of torrefied wood despite the reactor scale. Indeed, TGA and DSC measurements reveal that the more severe the torrefaction, the larger the amount of oxygen adsorbed on the wood surface [27] and the 
larger the exothermic heat flow generated by the reaction [27][28]. This is generally explained by an increase of the carbon content of wood [27][28] and/or by a increase of the reaction surface area with the severity of torrefaction [28]. These explanations suggest an increase of the number of reactive sites on the wood surface. Moreover, the severity of torrefaction might also affect the reactivity of these sites.

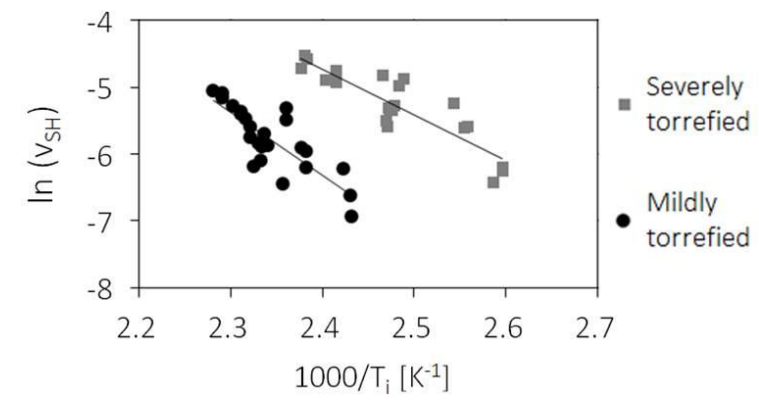

Figure 4: Arrhenius plot of the self-heating speed. Influence of the torrefaction severity at a flow rate of $30 \mathrm{NL} . \mathrm{min}^{-1}$.

The influence of the oxygen volumetric fraction and the gas flow rate on the self-heating speed is presented on Figure 5. Results concern the mildly torrefied bed with an initial temperature of $150^{\circ} \mathrm{C}$. It can be observed that a larger oxygen fraction increases the self-heating speed. This supports the idea of a non-zero order reaction according to oxygen. Under the lowest oxygen level (7\%), no significant selfheating was recorded. In the literature, self-ignition of wood appears to be also affected by an oxygen fraction as low as 7\% [32]. At constant oxygen fraction, the speed of the temperature rise is larger for low flow rate. As expected, the more heat is evacuated by advection, the lower the self-heating speed.

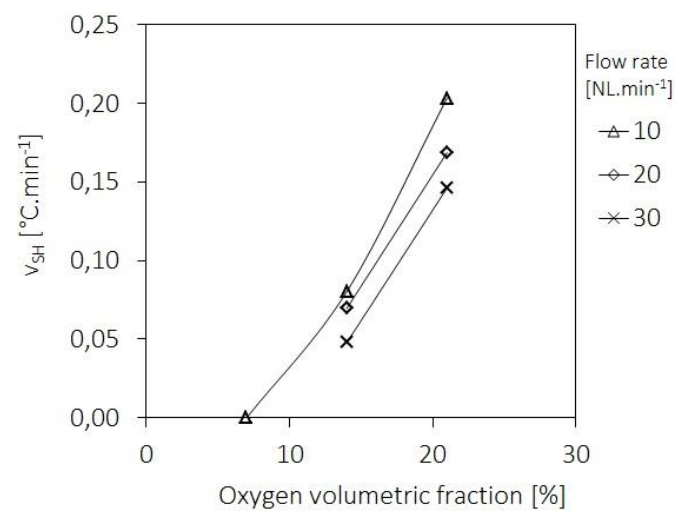

Figure 5: influence of oxygen volumetric fraction on the self-heating speed averaged over the altitude. Oxygen is introduced in the mildly torrefied bed at $150^{\circ} \mathrm{C}$. 
The influences of the gas flow rate and the torrefaction severity on self-heating propensity are also confirmed by the temperature at which thermal runaway occurs. Indeed, at an air flow rate of $30 \mathrm{NL}$. $\mathrm{min}^{-}$ ${ }^{1}$, self-ignition is observed at 150 and $160^{\circ} \mathrm{C}$ for the severely and the mildly torrefied bed, respectively. At an air flow rate of $10 \mathrm{NL} \cdot \mathrm{min}^{-1}$, self-ignition occurs at $150^{\circ} \mathrm{C}$ for the mildly torrefied bed. Noteworthy, ignition of the bed always starts on its top because of higher initial temperature. This particularity corroborates experimentally the hotspot problem related to self-heating. Indeed, locally warmer temperature facilitate the development of self-ignition [33]. In this critical state, if none of the experimental parameters is changed, a sharp increase of the temperature rise is observed, typically $60^{\circ} \mathrm{C} \cdot \mathrm{min}^{-1}$, followed by the combustion of the entire bed. However, by increasing the air flow rate or diminishing the oxygen fraction of the inlet gas phase, the combustion process can be restrained as shown in Figure 6.

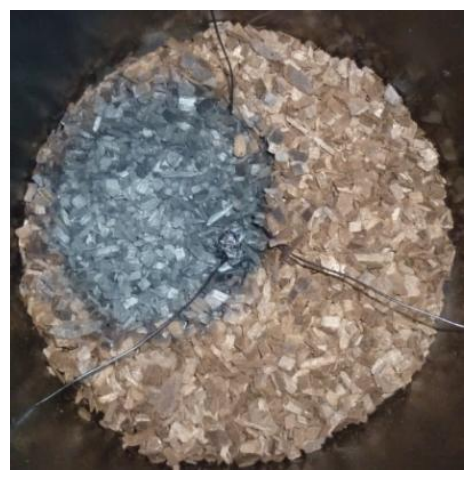

Figure 6: top view of the bed after onset of ignition stopped by increasing the inlet air flow rate or by diminishing the oxygen gas volumetric fraction.

\subsubsection{Generation of gaseous products}

Figure $7 \mathrm{a}, \mathrm{b}$ and $\mathrm{c}$ provide the evolution of the carbon oxides fractions at the outlet of the reactor filled with the severely torrefied chips at various initial temperatures. The molar ratio $\mathrm{CO} / \mathrm{CO}_{2}$ is also presented. One can observe that the higher the initial temperature, the higher the fraction of carbon oxides. Indeed, temperature increase accelerates both adsorption and decomposition reactions. Moreover, production of oxidative gas evolves differently depending on the initial temperature. At initial temperatures of $110^{\circ} \mathrm{C}$ 
and $120^{\circ} \mathrm{C}$, the carbon oxides fractions quickly reach a maximum and then decrease slowly. However, when oxygen is introduced at $130^{\circ} \mathrm{C}$ and $140^{\circ} \mathrm{C}$, the oxides fractions keep increasing during $30-50$ minutes before reaching a maximum value. Finally, a sharp increase is observed at the initial temperature of $150^{\circ} \mathrm{C}$, revealing that thermal runaway occurs. The same evolutions have been observed for carbon oxides productions when coal is exposed to air during a self-heating and a self-ignition [34]. As other parameters remain constant during the experiments, it is assumed that the self-heating temperature rise is large enough to influence the kinetic of the reactions taking place. The $\mathrm{CO} / \mathrm{CO}_{2}$ ratio has the same evolution but slightly more pronounced. Furthermore, it increases with the initial temperature. For coal, a previous study [34] also found a higher $\mathrm{CO} / \mathrm{CO}_{2}$ ratio when the initial temperature is raised. However, the production of $\mathrm{CO}$ starts earlier than the production of $\mathrm{CO}_{2}$, which was not the case in the results resented here.
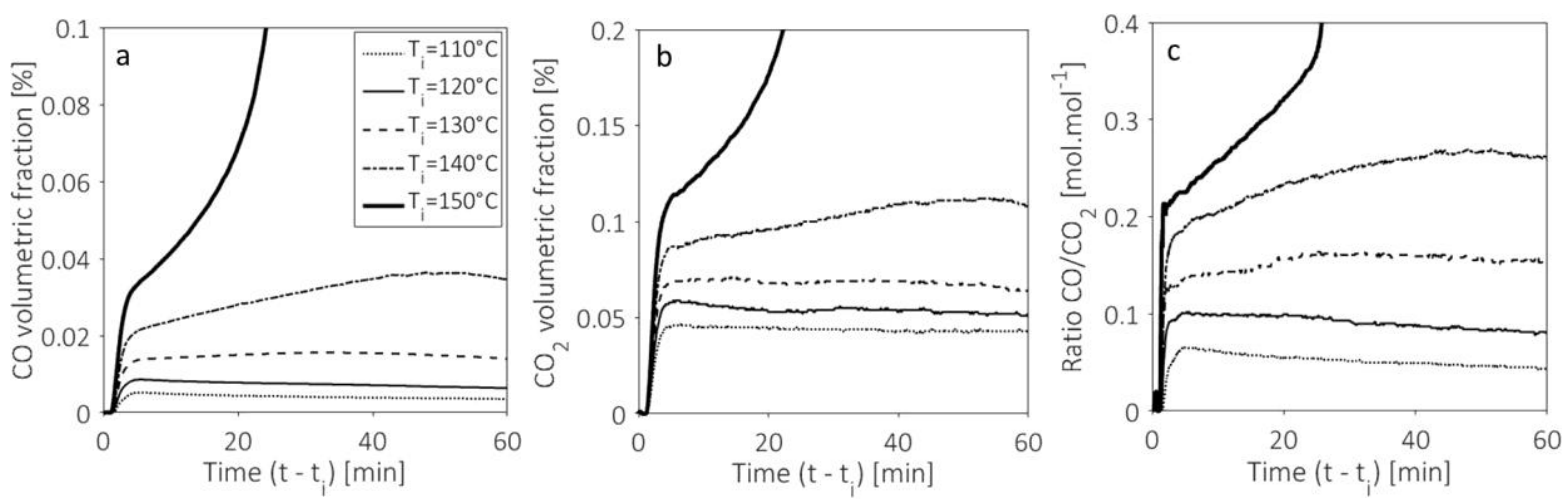

Figure 7: carbon monoxides (a), carbon dioxide (b) volumetric fraction and molar ratio $\mathrm{CO}$ to $\mathrm{CO}_{2}(\mathrm{c})$ at the outlet of the severely torrefied beds. Air is introduced at a flow rate of $30 \mathrm{NL} \cdot \mathrm{min}^{-1}$.

Figure 8 presents the oxygen fraction at the outlet of the severely torrefied bed. The oxygen fraction decreases when the initial temperature is raised because of higher amount of oxygen consumed by the reaction. 


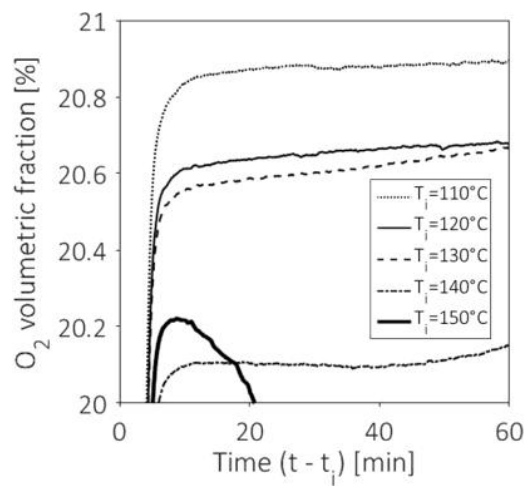

Figure 8: oxygen volumetric fraction at the outlet of the severely torrefied beds. Air is introduced at a flow rate of $30 \mathrm{NL} . \mathrm{min}^{-1}$.

Figure $9 a$ and b depict the peaks of oxygen consumed and carbon oxides produced, respectively, as a function of the initial temperature except when ignition occurs. The effect of the torrefaction severity and the air flow rate is presented. Torrefaction severity increases the amount of both oxygen consumed and carbon oxides produced. The flow rate seems to influence neither oxygen consumption nor carbon oxides production. However, for the mildly torrefied bed and an initial temperature of $140^{\circ} \mathrm{C}$, the calculated $\mathrm{CO} / \mathrm{CO}_{2}$ ratio is multiplied by a factor two when the air flow rate decreases from 30 to $10 \mathrm{NL}$. $\mathrm{min}^{-1}$. The study [35] investigates the influence of the ventilation rate on coal self-heating. In contrast to our experimental observations, the $\mathrm{CO} / \mathrm{CO}_{2}$ ratio remains more or less constant under different flow rates. This might be explained by the use of different raw material and/or by the use of different particle and bed sizes.
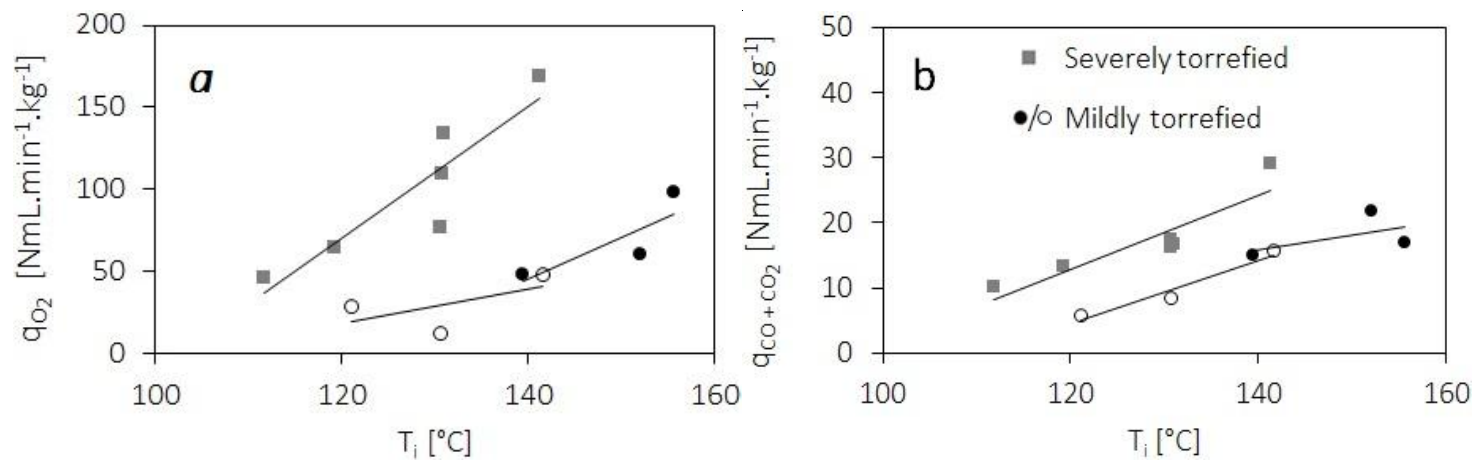

Figure 9: oxygen consumption (9a) and carbon oxides production (9b) vs initial temperature. Fill and blank dots are used for a flow rate of $30 \mathrm{NL} . \mathrm{min}^{-1}$ and $10 \mathrm{NL} \cdot \mathrm{min}^{-1}$, respectively.

Carbon oxides, water and aliphatic hydrocarbons were measured by [26] as gaseous products generated by the low temperature oxidation of wood. However, [27] shows that the amount of water and aliphatic 
hydrocarbons generated are weak compared to the amount of carbon oxides produced. Moreover, it can be assumed that the oxygen atoms contained in the torrefied wood are stable because the rate of the pyrolysis reactions are low at these temperatures [3]. Finally, the oxygen molecule balance can be calculated according to equation (6).

$$
q_{\mathrm{O}_{2} \text { ads }}=q_{\mathrm{O}_{2}}-1 / 2 \cdot q_{\mathrm{CO}}-q_{\mathrm{CO}_{2}}
$$

Interestingly, the amount of oxygen molecules consumed by the bed is higher than the amount of oxygen molecules released in the carbon oxides. A quantity of oxygen molecules appears to be consumed and retained by the solid while the air crosses the torrefied beds. It is assumed that this amount of oxygen is adsorbed and forms oxygenated complexes onto the wood surface, as for coal [22]. Thus, the oxygen adsorption rate was calculated at the maximum carbon oxides released, which approximately corresponds to the maximum temperature overshoot. For a given temperature, the oxygen adsorption rate is higher for the severely torrefied bed than for the mildly torrefied bed. This supports the idea that the number of available reactive sites for oxygen adsorption is boosted when torrefaction temperature increases. Oxygen adsorption rate vs average self-heating speed is presented in Figure 10. A rough monotone dependency can be observed: the higher the self-heating speed, the higher the oxygen adsorption rate. Based on this graph, it is not possible to derive two distinct heats of adsorption for mildly and severely torrefied woods. However, coupling gas analysis and temperature monitoring during a self-heating might potentially help to obtain the heat of adsorption. This value can not be calculated separately from usual self-heating test methods [13] and is generally considered as a constant when modelling self-heating process [7]. 


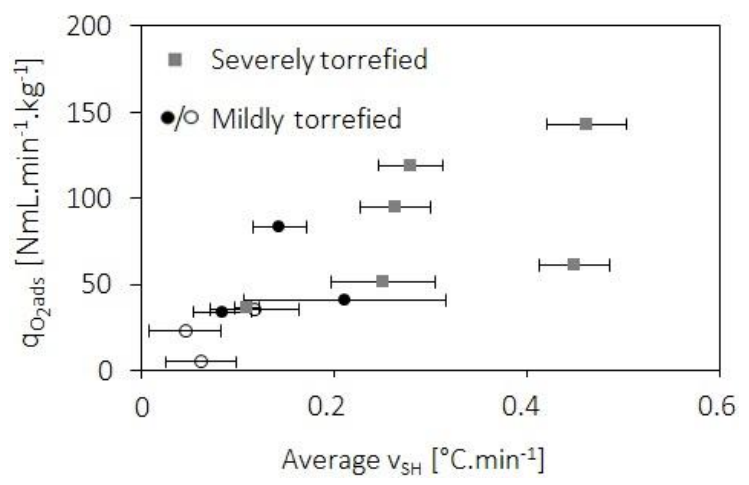

Figure 10: oxygen adsorption rate vs self-heating speed average over elevation in the bed. Fill and blank dots are used for a flow rate of $30 \mathrm{NL} \cdot \mathrm{min}^{-1}$ and $10 \mathrm{NL} \cdot \mathrm{min}^{-1}$, respectively.

\section{Conclusion}

Self-heating experiments at the reactor scale is a compromise between industrial scale self-heating, where phenomena are not well controlled, and microscale experiments where self-heating can not be observed.

Thermal measurement results presented in this study clearly show an increase of self-heating and selfignition propensity with the severity of torrefaction. This result indirectly corroborates the previous findings on the reactivity between oxygen and torrefied wood. In the context of production scale up, attention should be paid on the process safety, especially if severely torrefied wood is produced.

Results of the output gas analysis reveal an adsorption mechanism pathway. Oxygen adsorption on the wood surface is enhanced by torrefaction severity and explains its easiness to self-heat and self-ignite. The result is still not clearly explained and deserves future investigations. Moreover, the heat associated to the adsorption reaction might also change with the severity of torrefaction.

Finally, this work provides new experimental data of temperature evolution during a self-heating which are of interest in the perspective of process modeling.

\section{Acknowledgments}

The authors would like to thank the region Occitanie and École des Mines de Saint-Étienne for funding the project, Mickael Ribeiro and Denis Marty for their technical support. 


\section{References:}

[1] Chen W-H, Peng J, Bi XT. A state-of-the-art review of biomass torrefaction, densification and applications. Renew Sustain Energy Rev 2015;44:84766.doi:http://dx.doi.org/10.1016/j.rser.2014.12.039.

[2] Wild M, Michael D, Hektor B, Hess JR, IEA Bioenergy. Possible effects of torrefaction on biomass trade. IEA Bioenergy Task 40. 2016.

[3] Bergman PCA, Boersma AR, Zwart RWR, Kiel JH. Torrefaction for biomass co-firing in existing coalfired power stations. 2005.

[4] Bergman PCA, Boersma AR, Kiel JH, Prins MJ, Ptasinski KJ, Janssen FJJG. Torrefaction for entrainedflow gasification of biomass. 2005.

[5] Koppejan J, Sokhansanj S, Melin S, Madrali S. Status overview of torrefaction technologies. IEA Bioenergy Task 32. 2012.

[6] Thrän D, Witt J, Schaubach K, Kiel J, Carbo M, Maier J, et al. Moving torrefaction towards market introduction - Technical improvements and economic-environmental assessment along the overall torrefaction supply chain through the SECTOR project. Biomass and Bioenergy 2016:1-17. doi:http:// dx.doi.org/10.1016/j.biombioe.2016.03.004.

[7] Cocchi G. The relationship between thermal diffusivity, energy of activation and temperature rise in subcritical self heating of fuels in simple geometries. Fuel 2015;158:816-25. doi:http://dx.doi.org/10.1016/j.fuel.2015.06.037.

[8] Koppejan J, Lönnermark A, Persson H, Larsson I, Blomqvist P, Arshadi M, et al. Health and Safety Aspects of Solid Biomass Storage, Transportation and Feeding. IEA Bioenergy task 32. 2013. 
[9] Franck-Kamenetskii D. Diffusion and heat transfer in chemical kinetics (2nd edition). Plenum Press 1969.

[10] Chen X, Chong L. Some Characteristics of Transient Self-Heating Inside an Exothermically Reactive Porous Solid Slab. Process Saf Environ Prot 1995;73:101-7.

[11] Jones J, Chiz P, Koh R, Matthew J. Kinetic parameters of oxidation of bituminous coals from heatrelease rate measurements. Fuel 1996;75:1755-7.

[12] Herbig C, Jess A. Determination of reactivity and ignition behaviour of solid fuels based on combustion experiments under static and continuous flow conditions. Fuel 2002;81:2387-95. doi:10.1016/S0016-2361(02)00177-1.

[13] Malow M, Krause U. The overall activation energy of the exothermic reactions of thermally unstable materials. J Loss Prev Process Ind 2004;17:51-8. doi:10.1016/j.jlp.2003.09.002.

[14] Bowes P. Self Heating: Evaluating and Controlling the Hazards. Elsevier Sci 1984.

[15] Smith A, Miron Y, Lazzara C. Large-Scale Studies of Spontaneous Combustion of Coal. Spokane: 1991.

[16] Browne CA. The Spontaneous Combustion of Hay. Washington: 1929.

[17] Verhoeff F, Kiel J, Zwart R. ECN's moving bed torrefaction technology in light of desired product qualities 2012:27.

[18] Wilèn C, Jukola P, Järvinen T, Sipilä K, Verhoeff F, Kiel J. Wood torrefaction - pilot tests and utilisation prospects. Helsinski: Julkaisija Utigivare; 2013.

[19] Wang H, Dlugogorski BZ, Kennedy EM. Coal oxidation at low temperatures: Oxygen consumption, 
oxidation products, reaction mechanism and kinetic modelling. Prog Energy Combust Sci 2003;29:487-513. doi:doi:10.1016/S0360-1285(03)00042-X.

[20] Gethner JS. Thermal and oxidation chemisrty of coal at low temperature. Fuel 1985;64:1443-6.

[21] Hart PJ, Vastola FJ, Walker PL. Oxygen Chemisorption on Well Cleaned Carbon Surface. Carbon N Y 1967;5:363-71.

[22] Wang H, Dlugogorski BZ, Kennedy EM. Analysis of the mechanism of the low-temperature oxidation of coal. Combust Flame 2003;134:107-17. doi:10.1016/S0010-2180(03)00086-5.

[23] Tremblay G, Vastola FJ, Walker PLJ. Thermal Desorption Analysis of Oxygen Surface Complexes on Carbon. Carbon N Y 1977;16:35-9.

[24] Brown TC, Lear AE, Haynes BS. Oxygen Chemisorption on Carbon. Coal Combust 2006;24:1199_ 206.

[25] Bradbury AGW, Shafizadeh F. Chemisorption of Oxygen on Cellulose Char. Carbon N Y 1979;18:109-16.

[26] Derychova K, Perdochova M, Veznikova H, Bernatik A. The composition of gaseous products of lowtemperature oxidation of coal mass and biomass depending on temperature. J Loss Prev 2016;43:203-11. doi:10.1016/j.jp.2016.05.022.

[27] Candelier K, Dibdiakova J, Volle G, Rousset P. Study on chemical oxidation of heat treated lignocellulosic biomass under oxygen exposure by STA-DSC-FTIR analysis. Thermochim Acta 2016;644:33-42.

[28] Catalina D, Ceballos C, Hawboldt K, Hellleur R. Effect of Production Conditions on Self-heating Propensity of Torrefied Sawmill Residues. Fuel 2015;160:227-37. 
[29] Cavagnol S. Approche multi échelle de l'emballement des réactions exothermiques de torréfaction de la biomasse lignocellulosique : de la cinétique chimique au lit de particules. Ecole Centrale Paris, 2014.

[30] Nocquet T, Dupont C, Commandre JM, Grateau M, Thiery S, Salvador S. Volatile species release during torrefaction of wood and its macromolecular constituents: Part 1 - Experimental study. Energy 2014;72:180-7.

[31] Alder J, Enig JW. The Critical Conditions in Thermal Explosion Theory with Reactant Consumption. Combust Flame 1964;8:97-103.

[32] Malow M, Krause U. Smouldering combustion of solid bulk materials at different volume fractions of oxygen in the surrounding gas. Fire Saf Sci 2008:303-14. doi:10.3801/IAFSS.FSS.9-303.

[33] Brindley J, Griffiths JF, Mclntosh AC. Ignition phenomenology and criteria associated with hotspots embedded in a reactive material. Chem Eng Sci 2001;56:2037-46. doi:10.1016/S00092509(00)00429-2.

[34] Yuan L, Smith AC. Experimental study on CO and CO2 emissions from spontaneous heating of coals at varying temperatures and O2 concentrations. J Loss Prev Process Ind 2013;26:1321-7. doi:10.1016/j.jp.2013.08.002.

[35] Yuan L, Smith AC. CO and CO2 emissions from spontaneous heating of coal under different ventilation rates. Int J Coal Geol 2011;88:24-30. doi:10.1016/j.coal.2011.07.004. 